\title{
The Place of Africa in the International Community: Prospects and Obstacles
}

\author{
Adams 0100 \\ Department of Political Science and Public Administration, University of Nairobi, Nairobi, Kenya \\ Email: adams_oloo@yahoo.com, aoloo@uonbi.ac.ke
}

Received 1 April 2016; accepted 16 April 2016; published 20 April 2016

Copyright (C) 2016 by author and OALib.

This work is licensed under the Creative Commons Attribution International License (CC BY). http://creativecommons.org/licenses/by/4.0/

(C) (i) Open Access

\section{Abstract}

This paper traces the evolution of Africa's engagement from the pre-Cold war era to date demonstrating the ways through which Africa has attempted to gain a foothold in the international arena. The key question that we seek to answer is whether Africa has the political clout to change the dynamics of engagement in international institutions and whether that clout is enough in terms of influence and policy outcomes. For Africa to become an important actor in international politics, it must strategically use its numbers and the shared history to overcome the challenges of lack of economic and military power which forces it to enter into agreements with high and mid-level powers as well as multinational corporations that undermines their capacity to influence affairs at the global arena. This will most likely be achieved through pushing for the reform of the international system and integrating their approach of relation with external actors.

\section{Keywords}

International Politics, International Organisations, Cold War, Post-Cold War, African Voice, Democracy, Development, Security, Reforms

Subject Areas: Politics

\section{Introduction}

Africa remains an underdog in international politics and as a result their influence in international organizations is at best marginal and of no effective influence in operationalization of international politics. Despite the recent increase in quota and voice of Africa in global politics the general observation is that African effective representation still looms large and they are yet to acquire a voice as such in the international arena.

There are a myriad of organizations that fall under the bracket of the international community. These organizations include the European Bank for Reconstruction and Development, Food and Agriculture Organization of the UN, Group of 77, Inter-American Development Bank, International Atomic Energy Agency, International 
Council on Human Rights Policy, International Court of Justice, International Labour Organization, International Maritime Organization, International Monetary Fund, International Organization for Migration, International Organization for Standardization, International Seabed Authority, International Telecommunications Union, Organization for Economic Cooperation and Development, United Nations Security Council, United Nations Development Program, World Bank, World Health Organization, World Meterological Association, and World Trade Organization. These are the institutions of global governance that dominate and regulate international relations and the majority of their decisions that impact on African countries both positively and negatively. It is for these reasons that the majority of African leaders are of the opinion that for them to have a say in deliberation of issues that affect the continent in a major way then it is only fair that they are given an equal in their deliberations.

There are a number of international organizations where Africans have been able to register some effective representation, like the WTO and WHO. This has been as a result of the veto power they possess in lieu of the numbers that they have in these organizations. But again there is a general feeling that the entities in which African countries have a voice have limited or no consequences on the agenda and policy direction in the international arena.

African players at the international arena have realized that the only way they can forge a distinct role in the international diplomatic game and have significant impact in multilateral processes is when they act as a regional block. These initial gains are being felt in the trade and climate change issues where Africa has exerted blocking power to ensure that their input on issues affecting them are taken into consideration.

The article attempts to trace the evolution of African representation in the international community from the cold war era to the post-cold war era and the related dynamics at play that influence the attempt of African to be heard at the international level. While tracing this evolution we also look at ways through which Africa has attempted to influence processes at the international level; the players and actors that have been involved in this struggle and what options are available to the continent in its quest for greater influence as well as integration in the international arena. The key question that we seek to answer is whether Africa has the political clout to change the dynamics of engagement in international institutions and whether that clout is enough in terms of influence and policy outcomes.

\section{Africa and the International Community: A Brief History}

In international institutions, developing countries have over the years been grossly underrepresented. This can be alluded to the fact that they were late entrants into the international diplomatic game after attaining independence when most of the contemporary international governance regime was already in place and the rules of engagement were already in play. With this late entry into international politics, the African group tried to coalesce around themselves, through initially forming the Non-Aligned Movement (NAM) to advance their own interests in world affairs and project their perspectives on key global issues. Within the greater UN system, they established the G77 group of countries to push their collective concerns through reciprocal solidarity. Very early on, through the NAM and the G-77, the South-South grouping was able to press their case for major reforms in global governance and for a new international economic and communications order [1].

There are, of course, different types of international organizations that comprise the international community. There are those that rely on the use of authoritative, forceful, or sanctioning nature to ensure compliance, like for example the UNSC, or those that rely on policy tools that provide capacity or resources or otherwise, for example WTO and ICJ. African representation is well represented in the latter vis-à-vis in the former. But again there are scholars who argue that this representation is not effective in the sense that the major powers of the world are really significantly not affected by the deliberations of such international entities. They portend that powerful states had an interest in either not participating in such organizations and maintaining the power that they would have foregone as a condition of participation, or controlling as much of the policymaking body of the organization as possible in order to exert influence on its outcomes [2].

These scholars provide the example of the UN General Assembly to illustrate their case. They point out that as more countries gained independence and the face of the UN General Assembly was forced to change since the system for passing resolution was based on one-county-one-vote, big powers could no longer fully dominate the Assembly. Consequently, they shifted to the UNSC as the effective and more manageable site for pushing and bargaining their competing interests in a polarized world. This left the Assembly as a mere talk-shop which at best could only muster a moral authority. Yet, the UNSC also saw countries frequently resorting to the veto, which 
produced regular gridlocks in international governance broken only by the competing powers taking open or clandestine unilateral action [3] [4].

The multilateral system operates according to the whims of the big powers who prefer that way as they have the opportunity to act both within and outside their rules. Most of the international institutions are operated according to the whims of the big power interests. For example, the Bretton Woods institutions became tools aligned to the global strategy of the G7 countries led by the US. In the UNSC, where interests between developing and developed states are competing for relative power position, only 21.4 percent of the African population had a direct representative in the voting bloc regardless of the fact that a majority of UNSC policies affect African states directly. Conversely, in the WHO, where interests are convergent and incentives exist to cooperate, the voting structure is more egalitarian with each member-state possessing one vote in the World Health Assembly. Both African and North American citizens are represented equally at 100 percent [5].

The Security Council's five permanent members-China, France, Russian Federation, the United Kingdom and the United States-were designated in 1945 and have since remained unchanged. While 10 non-permanent members have been added, including South Africa and Nigeria, these members do not have veto power and can only serve non-concurrent two-year terms. To date, both Africa and Latin America lack representation among the Security Council's powerful permanent members.

The UN's leadership in generating ideas and formulating broad economic perspectives for effective global co-operation was severely eroded by the less transparent IMF and World Bank, where weighted voting allowed the US and its allies to shape and impose global economic governance policies. It was more than a passing coincidence that from the late 1960s into the early 1980s, the UN was where members of NAM (most of whom were also in the G77) campaigned for a new international economic order and, most notably, pushed for a UN conference on trade and development, among other such initiatives. The shift by the US and its allies towards the Bretton Woods institutions, to the detriment of the UN, significantly expanded the IMF and World Bank's influence in economic management and broader policy processes of the NAM/G77 countries; the Executive Committees of the Bank and the Fund were also effectively dominated by the G7 countries.

A good case of the big powers reluctance to adhere to the rules of international engagement is the ICJ. Since the establishment of ICJ to date, no permanent member of the UNSC has been subject to any compulsory jurisdiction: the most obvious example being the abrogation of assent to compulsory jurisdiction by the United States in 1984 after the ICJ rendered a decision unfavorable to the US position by asserting jurisdiction over a case brought by Nicaragua [6] [7]. Evidently, the power originally vested in the institution for the settlement of international legal disputes has been somewhat marginalized by the fact that states that do not consent to the terms of adjudication are not subject to the jurisdiction of the court. In spite of this fact, all the permanent members of the UNSC have a jurist sitting on the panel of the fifteen judges that adjudicate cases before the ICJ. This clearly shows that even though the affairs of the court do not affect them they still control the agenda and direction of international legal standards to reflect their interests and agendas [2].

In the Bretton Woods Institutions (BWI), the framework that has existed for many years is that many of the major policy decisions are taken by the executive boards of the BWI where developing countries are underrepresented in terms of membership. For instance, forty seven sub-Saharan African countries are represented at the boards of the IMF and the World Bank by two executive directors. World Bank recently added a third executive director for SSA. These directors have relatively, large constituencies, making it difficult to ensure that the diverse interests of African countries are adequately represented in informal processes that influence final decisions. African countries' participation in the WTO has previously been very limited. With the exception of South Africa, no other country in Sub-Saharan Africa has been involved in the WTO's Dispute Settlement Mechanism, as either complainants or respondents. With the current trend of rising protectionism in developed countries, it will be important for African countries to take a more active role in the WTO to safeguard their trade gains.

There have been some developments with regard to Africa's place in the international hierarchy. Some sorts of cooperation have begun to take place ever since the transformation of OAU into AU and the coming into being of the AU security architecture, NEPAD and APRM. The big powers, especially though the UN and the Bretton Woods institutions, have endeavored to work and listen to Africa through these arrangements-priorities regarding development objectives which are crucial to African development have begun to take root in international politics.

The international community has been instrument in providing financial and technical capacity of the development of these organizations. The UN has been very instrumental in providing a central building block AU's 
emerging peace and security system. The UNECA has been instrumental in the setting up and development of the capacity of NEPAD and APRM. It has been instrumental in developing a set of initiatives that respond to NEPAD's broad peace and security, stability, democracy and sustainable development objectives. Through its subprogrammes ECA continued to provide technical support for the implementation of the NEPAD programme. This support was vital for developing and supporting the implementation of the various AUC/NEPAD programmes. In addition, ECA supported the transition of the NEPAD secretariat into a fully-fledged technical unit of the AUC. Specifically, ECA supported the development of NEPAD Agency's Strategic Direction and its subsequent alignment with the AUC's Strategic Plan, and also helped the Agency to develop its knowledge management platforms. ECA also continued to house and provide human resources for the operations of the RCM-Africa secretariat. Support for APRM activities included technical support for the APRM Panel and preparation and analysis of assessment questionnaires. During the period under review, UN agencies continued to provide support to APRM missions. They collaborated in a study leading to the development of guidelines on the design, implementation and monitoring of the National Plan of Action that will ensure consistency and harmonization between National Plans of Action and existing national development strategies, to be used by technical research institutes, national governing councils or commissions and government departments and agencies that are involved in the APRM process.

A Declaration on the ten-year capacity-building programme, signed by the UN Secretary-General and the AUC Chairperson, builds on previous agreements between the UN and the AU and provides a holistic framework for the UN system to support the capacity development efforts of the AU and the regional economic communities, on the basis of the latter's needs and strategic priorities. The programme is aimed at enhancing cooperation between the $\mathrm{UN}$ and the AU in their areas of competence, in conformity with their mandates.

Indeed, Africa's participation in international and multilateral diplomacy has grown significantly and become more complex. This has placed great demands on Africa's capacity to negotiate and implement deals to its advantage. Given its long standing challenges with a high incidence of poverty, disease and conflict and its marginalization in international affairs especially during the cold war, Africa has come to the realization that with growing multilateralism in the post-cold war era it needs to use its numbers better by advancing common positions in international negotiations. The power of having large numbers of states would be of no value in multilateral diplomacy unless Africa took coherent and concerted negotiation positions during increasingly complex international negotiations on global challenges that tend to have Africa as their epicenter [8]. Consequently, the number of common positions and platforms by African countries in international diplomatic forums has increased since the mid-1990s. This has enabled the African Group in the UN and other platforms to play a much more distinct role in international diplomacy than in the past.

The role of African countries in the WTO, as well as in the climate change arena has also been driven by attempts by African states to utilise its advantage in the numbers game in international forums [8]. The results have been patchy. In the case of UN reform, the Africa common position outlined in the Ezulwini Consensus was arrived at through a consensus-forming process that resulted, because of the need to accommodate such disparate interests, into an implausible and inflexible negotiating position that left Africa marginalized in the UN discussions [8]. Influence in the Copenhagen negotiations was greater and the common Africa position was a first for the AU [9]. But even there the collective position could not withstand the centrifugal pull of national interests, South Africa taking a key role in the drafting of the Copenhagen Accord out-with AU oversight after pre-summit bilateral deals and splits between Ethiopia and Sudan had undermined AU cohesion on the issue [8] [9].

African states have a greater influence and potential role in the WTO than they do in any other international economic institution. African states have used this potential to take advantage of schemes within the WTO that enhance the role of poor countries. Regional organisations such as the African Union and the Southern African Development Community (SADC) have facilitated the involvement of African states, which now constitute a third of the WTO's membership and thus have become integral to influencing the process but not the substantive content of trade policy issues. This has particularly been the case in The Doha Round of trade negotiations.

But whether this idea of an African Group and its common negotiating positions will affect Africa's relations with global power and globalization depends on how they have enhanced Africa's position in multilateral diplomacy and led to a clear definition of Africa's collective or common interests. It is also inextricably linked to the idea of neutralizing the dominant neo-liberal agenda and the divisive influence of external powers on intra-African affairs.

Right from the start, the African group and other alienated groups were obsessed with the reform of the world 
order already in place because that is the only way that their interests could find a place on the agenda of international politics. The main agenda of their proposals has always been the:

1) Reform of the UN system in general, and the UNSC in particular, with a view to broadening representation at the highest levels of global decision making, and to disciplining the use of the veto by the big powers in order to prevent the routine subversion of the will of the international community;

2) Recalibration of the voting rights and decision-making processes of the IMF and the World Bank, to ensure a greater voice for the countries of Africa, Asia and Latin America;

3) Generalized reform of the international trading system, to make it fairer, remunerative and development-oriented;

4) Creation of a global integrated programme for commodities (agricultural and mineral) that would assure more stable and fairer prices;

5) Creation of a new global currency, based on the special drawing rights, that could safeguard the development interests of all members of the international community;

6) Adoption of rules that would govern the conduct and practices of Western transnational companies in the economic and political spheres, as well as in matters of technology transfer, patents, and copyrights;

7) Adoption of a global tax on the brain drain, to ensure that less developed countries would receive some form of compensation for losing skills to more advanced countries; and

8) Reform of the global information and communications order, to allow for greater North-South balance.

To date these proposals still form the aspirations of the African group in their quest for a greater say in world affairs. To date, African countries form the largest regional grouping at the UN, with over a quarter of all UN member states. Yet group size per se does not automatically translate into pro-active, unified decision-making. On the contrary, speaking with one voice at the UN and synchronizing their position has become an ongoing challenge for African Member States to the UN.

\section{Africa's Voice in the International Community: From the Cold War Era to the Post-Cold War Era}

The effects of the cold war bipolar politics was best felt in Africa. Both cold war blocks had their own interests in Africa and it was unlikely to reach a consensus in the UNSC on matters involving African politics where each group has its own sphere of influence. This nature of relations in international politics ensured that Africa did not have a say in the running of international politics especially in affairs that affected issues dear to them. In spite of this state of affairs, African states were able to play one superpowers against the other in a bid to extract concessions.

The post cold war global structure has produced opportunities for structured cooperation in international peace and security with economic development as one of the essential elements of stability. The African group has endeavored to build a united approach in matters of world affairs and speak with one voice. However, this approach has dogged with a myriad of challenges especially where there is a strong national interest, such as security issues and conflict situations. In such scenarios, the African group has suffered the incapability of fronting a united position in either negotiations or voting.

The immediate post-cold war period up to the 1990s was dominated with different approaches to solving African problems by international institutions. The majority of these approaches were decided by the super powers with limited or no input from the African continent that the same policies were going to be implemented. A case in point is the Structural Adjustment Programmes (SAPs). The negative impact of these policies on African economies as well as other sectors is well documented and need not detain us here. The point to be made is that these programmes have been counterproductive for the very reason that there was no Africa voice in the formulation of these policies to offer an insight that would have been valuable to domesticate the policies [10]. Among other effects, they have compounded rather than ameliorated the deleterious conditions they were originally meant to alleviate. Consequent on their emphasis on the liberalisation of economies, for example, local industries have collapsed causing an escalation in unemployment. With their devastating impact on women and the vulnerable sections in society, SAPs have been blamed for the deepening of poverty in much of Africa, and partly for the growing indebtedness of the region [3]. But more relevant for this discussion, adjustment programmes have deepened the dependence of implementing countries not only on imports but also on international creditors. The latter scenario has led to the strengthening of the international economic relations between adjusting African states and the supplier countries of their imports. 
It is during the 1990s, that the African voice begun to be felt in the international institutions as African players began to aggressively push for integration into the system. A number of international institutions begun to undergo restructuring during this period. A system of multilateral approaches to international security intervention, for example, emerged under the auspices of the UN and regional organizations. The institutional cooperation between OAU and UN witnessed some drastic and constructive changes like the establishment comprehensive approaches to peace making and peace-building. Cooperation between different organs of international institutions and the African group under the auspices of the AU begun to take root. This period saw the African leadership begin to bemoan the perceived indifference of the international community and began calling for African solution to African problems through utilization of sub-regional arrangements to address local peace operations [3] [11].

The period from 2000-2007 witnessed the transformation of OAU into AU and ushered a new African vision aimed at the regeneration of the continent. It is during this period that NEPAD came into being and would become the pivot platform under the auspices of the AU that the African group would soldier on with their quest for greater say in the affairs of the world, more specifically in matters affecting the continent. This rebirth of the African voice ensured that socio-economic development of Africa became an integral part of the international initiatives, most of which revolved around peace and security_-from then henceforth building and strengthening of a peace and security mechanism was a sine qua non for Africa's development

Greater cooperation between the international community and the Africa Group slowly began to evolve. It is during this period that the development and implementation of the UN ten-year plan for capacity building with AU took shape. This development was to impact on NEPAD which has hitherto been accepted as the blueprint of the UN cooperation and engagement in Africa, including issues of peace and security. It is also during this period that Africa intensified its initiatives to speak as one voice. In March 2005, the AU issued a declaration known as The Common African Position on the Proposed Reform of the United Nations: The Ezulwini Consensus which was a statement in response to the Report of the High-Level Panel on Threats, Challenges and Change which was issued in December 2004. In this Common African Position the AU highlighted issues pertaining to HIV/AIDS and security, poverty, debt, environmental degradation, trade negotiations, the responsibility to protect, peacekeeping and peacebuilding. In addition, the AU called for further reforms of the UNSC to ensure that the Council was inclusive and that the African is fully represented in all the decision-making organs of the UN, particularly in the Security Council. The African Group demanded not less than two permanent seats in the UNSC with all the prerogatives and privileges of permanent membership including the right to veto and "five non-permanent seats". This decision subsequently locked the AU into trying to maintain this position in the face of tremendous pressure from other members of the international community notably by the Group of four (G4) Brazil, Germany, Japan, and India, which were aspiring for a permanent seat at the Council and the Uniting for Consensus coalition, which opposed their ambitions. This was in effect a bold move for the AU to have taken which was informed more by principle than by realpolitik, as indicated in the Ezulwini Consensus document which states that "even though Africa is opposed in principle to the veto, it is of the view that so long as it exists, and as a matter of common justice, it should be made available to all permanent members of the Security Council” [5].

At least on paper the AU was endeavouring to establish and maintain a common position. However, due to internal dissension some African countries particularly Egypt and South Africa effectively broke rank with the Ezulwini Consensus and sought ways to individually ascend to become permanent members of the Security Council. This in effect undermined efforts to demonstrate African "unity of purpose". This is further reinforced by the fact that time and again African countries have shown that they are unlikely to vote as a collective on matters before, or pertaining to, the Security Council. Governments generally tend to adopt positions that best serve their interests or positions that enable them to receive certain benefits from more powerful countries that pick and choose which African countries they want to work with. Therefore, the logic of "national self-interest" and political realism still prevails among African countries, and other member states, at the UN (Akokpari, 2001).

The Africa Group has a rotating monthly chairperson who is a Permanent Representative of one of the constituent African countries to the United Nations. The chairperson convenes meetings of the Group and establishes the negotiation agenda on key issues of vital Pan-African interest. In terms of the record of the Africa Group, on some issues African countries often find consensus for example on development, trade, debt cancellation, infectious diseases, small arms and light weapons, nuclear, chemical and biological weapons, climate negotiations, trans-national crime prevention and on the election of Africans to various UN activities and bodies. For example, the official statement of the Africa Group on the draft 2005 Outcome Document was issued through the office of the Permanent Observer Mission of the African Union to the United Nations. On some of these issues the Africa 
Group occasionally aligns itself with the Group of 77 (G-77) countries and China to increase its negotiation strength [3].

From the period 2008 to date has witnessed the African Group engaged in maneuvers geared towards the forming of formal links as a crucial step towards enhancing the symbiotic relationship between the UN and the AU. Slowly, the continent's voice is being integrated into the murky waters of global politics. This impact has been greatly felt in the international entities such as the WTO. The General Agreements on Tariffs and Trade (GATT) system in place before its transformation into WTO was from its inception dominated — and ordered - by the dominance of the US and from the 1960 onwards by the balance of power between the US and the EU. Many African countries enjoyed very little, if any influence, in multilateral trade governance. Although most African countries were members of GATT, histories of the eight multilateral trade rounds conducted during GATT period (1948-1995) indicate that African member states were largely absent from these negotiations. On the contrary, the WTO has since its inception in 1995 been multipolar and has ensured increased African participation [8].

African states have become more active and embedded into the WTO negotiating process. African states have insisted throughout the DDA negotiations that a discourse of development should predominate. When development issues have been sidelined African members have vetoed any potential WTO agreement on issues they see as detrimental or indifference to their development interests [8].

Evidently, the post-cold war period has witnessed increased international intervention in Africa, especially in peace operations. This period has also witnessed an upsurge in Africa's say in these interventions especially in the area of capacity building to tackle emerging challenges. Various initiatives have undertaken to formalize engagement between the international community and African actors to ensure that Africa's development priorities are integrated into UN architecture for peace and security in Africa since it has established that development is an "indispensable foundation" of collective security.

The jury is still out there as to whether African countries have sufficiently coalesced as a group and developed a coherent identity to effectively influence policy development at the international deliberations especially the UN.

\section{African Actors in the World Governance Realm}

African participation in global affairs has always revolved around the AU. However, with proliferation of alliances and coalitions, sub-regional actors also became integrated in international politics under the auspices of the AU. There are a number of actors involved. The most conspicuous players in international relations include: NEPAD, RECs, African Development Bank, African Economic Research Consortium, UNECA as well civil society organizations.

There is however a general consensus that most of these players lack sufficient voice in the key global institutions that Africans have been seeking integration. And while African governments lack sufficient voice, other African actors outside the realm of government are completely voiceless. A number of factors have been elaborated that impact on this state of affairs; that is, the inadequate technical capacity to express that voice; inadequate voting rights and structures in international organizations; and, inadequate groups to express African voices collectively, notably because a lot of groups are dominated by large middle-income countries.

In the recent days, African actors have resolved to coalesce around the African Group in order to speak as one voice and effectively lobby for greater African representation in global politics. This development is yet to solidify and continues to face challenges. But as long as Africa continues with this resolve to act as group without disintegrating during crucial negotiations and deliberation then the African Group will emerge as a substantive actor in address peace and stability, development and democracy in Africa [12].

\section{In Search of Democracy, Development and Security: Home Made Solutions or International Interventions}

Intervention by the global community in Africa's political, economic, military and cultural affairs has been accelerating since the end of the cold war and the intensification of globalization throughout the 1990s to the present. These interventions ensured that the international organizations served in policymaking capacity for states that are unable to design, implement, and enforce effective public policies through traditional domestic political institutions. This could be attributed to a lack of resources, the presence of an unstable environment, or a corrupt domestic government. Regardless, when an institutional void is created by ineffective domestic policymaking structures, global governance, often through international organizations, fills this void by governing the provision 
of goods to society. Those states that have the least influence in the design of global public policies are disproportionately affected by them.

The big question has always been whether these interventions have provided the best solutions to African problems or whether Africa should have resorted to homemade solutions to tackle African problems. The rallying cry by various African actors in global politics has been "African solutions to African Problems". But the question begs: can Africa tackle these problems on their own? Do we have effective and efficient institutional structures, and the managerial resources and capacity to go it alone? Can we manage without the financial, logistical and technical capacity of the international community?

Numerous studies have been carried to answer the questions posed above. But the results have been mixed and remain controversial. In a study on the impact of IFI programs in 76 African and Asian counties through 34 annual observations from 1974 to 2007, Limpach and Michaelowa attest to the mixed impact of the different types of IFIs implemented in Africa on the various dimension of democracy. The authors observe that "in a narrow sense, democratization cannot be imposed from the outside. We do not find significant effects of any type of IFI program on vertical accountability as measured by the degree of political participation and competitive elections in a country". On a different note, they also observe that "in a wider sense, however, IMF and World Bank programs do have political implications for changes in the extent of executive constraints and in the level of civil liberties in developing countries". Their main results reveal that the IFIs' traditional lending programs have negative short-term impacts on horizontal accountability in recipient countries, while their development policy lending to low-income countries increases horizontal accountability over the long term. In addition, this study shows that the IFI's PRS initiative strengthens civil liberties by promoting broad-based participation of civil society and, in particular the poor in the domestic political decision-making process [13].

In two other studies by Barro and Lee on IMF financial stabilization programs, they observe that these interventions have had a marginally negative effect, directly on democracy and indirectly on economic growth over the especially on democracy and economic growth contemporaneous and the lagged five-year period [14] [15].

On the contrary other studies have illuminated the positive impact that international intervention has had in Africa. The study by Nelson and Wallace [16] reveals that countries being under any kind of IMF program show significantly higher democratization levels, and concludes that the conditions attached to the loans disbursed by the IMF have a positive effect on the quality of democratic institutions in participating countries. These positive effects grow over time. For a one-year time lag, no apparent relationship between the participation in an IMF program and the level of democracy is detected. However, in the three-year and five-year lagged models, the coefficients for participating in an IMF program become stronger and statistically significant [16].

Similarly, the path-breaking study by Abouharb and Cingranelli [17] on the IFIs' human rights impact looks at the length of time a country has been under a structural adjustment program by either the World Bank or the IMF in the 1980 to 2003 period. The authors find that longer exposure to structural conditionality is positively correlated with procedural democracy. At the same time, their finding that long-term structural adjustment has a negative impact on a wide range of civil, worker and human rights points to the paradox that structural adjustment "may have led, simultaneously, to advances in procedural democracy and a decline in substantive democracy" [17].

Positive impacts of Poverty Reduction Strategy (PRS) processes are seen in three key areas, namely 1) that the PRS consultation process created new space for domestic policy dialogue and resulted in an unprecedented engagement of civil society organizations in poverty policy debates; 2) that the PRS process contributed to a much stronger focus on poverty inside government; and 3) that the PRS approach focused attention on donor coordination internationally and at the recipient country level (e.g., Booth 2003; Molenaers and Renard 2003; World Bank and IMF 2005; Driscoll and Evans 2005). However, a lot of challenges for achieving national ownership and democratic control of the PRS process are still remaining. They are mainly seen in the areas of institutionalizing sustainable participation and taking the domestic political context into account. Even though the ownership principle suggests participation of a variety of actors, in practice the PRS process was often characterized by "government ownership" rather than broader "country ownership" [18]. Moreover, governments often limited participation by depoliticizing the topics open for discussion and by politicizing the selection of participants [19]-[23]. Another challenge that has not attracted enough attention so far is that many PRS processes have unfolded in semi-democratized states in which domestic politics tend to be patronage-based, with fragmented party systems, politicization of administration, as well as weak state regulatory and implementation capacities. Some case studies indicate that there is a risk that PRS will become identified with the political party in power and be discarded when there is a change of government [24] [25]. 
In spite of the above state of affairs, in the past two decades there has been an incessant push for African solution to African problems. The African Group has been calling for the need for homemade solutions to tackle the problems bedeviling Africa. In support of their call they have attempted to come up with a series of initiatives aimed at enabling the continent deal with its own problems based on an agenda, managed by Africans and designed principally to promote and foster an African agenda. One of the most significant of the initiatives that emerged was the Conference on Security Stability Development and Co-operation in Africa (CSSDCA). More importantly, the challenges of peace and security became almost intractable.

The meeting concluded that Africa had to tackle the interrelated problems of security, stability, development and co-operation through its own means and to engage the rest of the world within a holistic and composite framework designed, owned and driven by Africans. The Africa Leadership Forum accepted the challenge to drive this process. In November 1990, it convened in Addis Ababa, Ethiopia, in collaboration with the Secretariats of the OAU and UNECA, a meeting of prominent African personalities drawn from government, business, academic, international and non-governmental organizations to brainstorm on concrete strategies to cope with the world's new realities. The meeting recognized the need to develop a framework for Africa along the lines of the CSCE. A Steering Committee, comprising about half of the conference participants, was set up to guide further activities in this direction. The committee restructured the principles into four main goals: security, stability, development and co-operation.

The CSSDCA process stresses the inter-linkage between peace, stability, development, integration and cooperation. It creates a synergy between the various activities of the African continent and seeks to consolidate the various critical issues relating to peace, security, stability, development and cooperation. The underlying thinking of the CSSDCA process was recognition of the fact that the problems of security and stability in many African countries had impaired their capacity to achieve the necessary level of intra and inter-African cooperation that is required to attain the integration of the continent, which is also critical to the continent's socio-economic development and transformation.

Indeed the premium on social and political stability was rising rapidly at a time when the changing international political framework had begun to marginalize the African continent and its concerns. There was also a growing awareness that the progress that the continent had recorded in the sphere of economic development left much to be desired and that poor economic performance underlined the rising wave of domestic conflicts

NEPAD, a new development programme, developed by African leaders, aims at tackling the continent's multi-faceted crisis, reflected in poor economic performance, bad governance, corruption and mismanagement, conflict and insecurity. More specifically NEPAD seeks to arrest and eradicate the deepening poverty on the continent; promote growth and sustainable development; halt and reverse the trend of the continent's marginalisation; and restore peace, security and stability. These are to be achieved in partnership with the international community especially foreign donors. In addressing these issues, NEPAD identifies certain key areas whose tackling enhances the achievement of its overall aims. These include peace and security, economic and corporate governance, infrastructure, agriculture, and access to international markets. The achievement of these objectives necessarily affects the continent's relations with the international community. In contrast to previous developmental paradigms, which required the bulk of the efforts from African states, NEPAD projects itself as a partnership between the continent and the international community to promote the development of the former. But, in seeking the partnership of the international community, NEPAD attempts to accelerate the integration of the increasingly marginalized African continent into the global economy. And although the NEPAD project emphasizes mutual partnership, Africa is heavily dependent on financial aid from the North.

Moreover, by relying on external funding, NEPAD is unlikely to change either the current configuration in Africa's international relations with the North or the contents of the former's foreign policies. On the contrary, the new development paradigm is not only certain to maintain Africa's weakness vis-à-vis the IFIs, but also deepen its dependence on international aid and thereby reinforce the centrality of aid in the continent's foreign policies. Globalization has generally been seen as posing major challenges to the African continent and NEPAD's quest to conform with it (through the latter's call for increased foreign investments and the adoption of neoclassical economic policies), rather than offering theoretical challenges to it, is seen as a potential source of failure of the new project to offer real alternatives for Africa. Furthermore, strengthening the donor-oriented posture of African states, NEPAD is poised to weaken intra-African relations. Since no African state demonstrates a capacity to provide economic assistance to a fellow African state, NEPAD may become a blueprint document legitimizing the outward-looking tendencies of African states [3]. 
While the African Peer Review Mechanism (APRM) more or less supplanted the CSSDCA and was given prominence over of it, the fact remains that security and stability remain the pillar upon which Africa can build its prosperity and relevance in the global market of development. The APRM is designed as a comprehensive mechanism based on the utilization of common diagnostic tools and measurement criteria for assessing performance and cross-referencing inputs for assessments from all stakeholders in African States and society. Though it provides the basis for continuous engagement of the political leaders on issue of governance, its implementation for almost eight years has not reduced the assertion made in this paper that internal security remains the most daunting challenge confronting development in Africa.

This is not to argue that Africa will not require outside assistance. Rather, it is to suggest that positive developments will depend, finally, on Africans developing “African solutions to African problems". Indeed, we believe that the only way that there can be positive outcomes in Africa is if African countries are no longer the junior partners on issues that most directly affect them. There is the real possibility of the continent growing faster and becoming more democratic and more secure while addressing critical social issues, especially the empowerment of women. Indeed, to a certain extent, success will breed success, as investors are attracted to growing economies, which will in turn cause them to grow even faster, thus attracting even more investment, in an ever-increasing upward spiral. Political stability will reassure those who lose elections that they need not go back to the bush to win political power, and the enrichment of the rural areas will bind countries together after decades when the minorities in the urban areas benefited disproportionately.

Assisting the development of the AU capacities to channel its own path in addressing African problems is where the international community should focus their priorities on. They main goal should be to ensure a structured interface between the AU and the international community.

The lack of economic and material resources is one of the biggest challenges that all democracy, development and security initiatives contend with in Africa. At present, funding from external donors is a necessity in order to improve capacity. NEPAD, AU and other initiatives engaged in democracy, development and security initiatives are largely funded by external actors. All operations are also greatly influenced by international expertise, advisors and companies. What African actors need to guard against is that this external funding is not accompanied by too much influence in decision-making processes or leadership [26].

Developments in Africa require increased international cooperation, which will need to be based on strong African leadership, internationally, regionally, nationally and at the various sub-state levels. The AU, NEPAD, the African regional organizations and its regional trade organizations will need to lead the way, with committed support from national leaders.

\section{The African Agenda and Options for Reforms}

The argument advanced by African countries for reform in the international governance system is primarily predicated on the need for greater justice and a more equitable representation in world affairs, with special emphasis on the institutions of global governance. Africa has the single biggest bloc of states in the General Assembly, yet does not have a permanent seat on the UNSC - complete with the power of veto. As outlined in the Ezulwini Consensus of 2005, the region has staked a claim for two permanent and five non-permanent seats. The continent has also added its voice to calls for the reform of the Bretton Woods institutions, and the restructuring of the existing weighted voting system, both to increase the African share of influence and to broaden the decision-making base. In recent years, routine invitations have been extended to selected African leaders to attend G7 meetings, usually sessions devoted to discussing the continent's problems and offers of aid. These invitations may have been designed as a gesture of inclusivity and solidarity that speaks simultaneously to Africa and the civil society/social movement critics of that forum's role in global economic governance, but have hardly succeeded in redressing the fundamental imbalances in the rules and operations of the international financial system. That is why, alongside the basic political governance issues, African countries also have a strong interest in pursuing a reform of the international development architecture [2] [8].

The forging of a new economic, social and political governance order that is the culmination of an accelerating global realignment process, is evidenced by the re-emergence of China along with India, Russia, and Brazil; the increased significance in global economic affairs enjoyed by the East Asian countries, Turkey, South Africa, Argentina, Saudi Arabia, and the Gulf States - to cite the most prominent new entrants; and the prospect of long-term decline that the old economic powers, many in the EU, face. It will be an order that will come complete 
with a radical redistribution of power, authority, and influence, and involve a rewriting/reinterpretation of rules pertaining to the global multilateral institutions. The old world order is gradually dying, while the new is struggling to be born. Debates have already been held and theories are presently being spawned about how such a new order might eventually emerge: by war or by peaceful means; through revolution or evolution; by negotiation, compromise-making and consensus-building or through politico-military fiat; or through a complex combination of all these elements. While interesting, the only relevance of these debates and theories to this paper is the extent to which they appear to be influencing the choices of major players regarding the need for change in the existing global governance order [2] [4].

Even as debates for more far-reaching changes continue, some changes have already been introduced, in the face of the existing global governance system's dysfunctionalities, and on account of direct pressures or changing objective realities. Within the UN system, high-level discussions for the reform of the General Assembly and the UNSC have been held and consultations continue. The UN family of organizations is looking at the need to work and deliver as "One UN", rationalizing and streamlining agencies with overlapping mandates in order to improve effectiveness and impact and to cut down on costs. Furthermore, recognizing the growing importance of non-state actors in global affairs, steps have been taken to accommodate voices such as those represented by global social movements and civil society groups, which not only wish to contribute to the governance agenda but also demand that increased accountability and responsibility be integral elements of change. Gender concerns, originally absent from the high tables of the UN, are now formally accepted and integrated into its work programme. The ICC has been grafted onto the broader governance system through the assiduous pressure mounted by civil society coalitions whose voices in world affairs are also growing in significance. The IMF and World Bank weighted voting systems have also been occasionally tinkered with in order, initially, to accommodate countries such as Japan and, more recently, Saudi Arabia and China, and to replenish the funds put at the disposal of the institutions. Membership, or prospective membership, of the WTO has also been opened up to some of the new or emerging global powers. Furthermore, for all intents and purposes, the G7 has been replaced by the G22, which is the new global forum of the powerful for governing the world economy. It is a process of inclusion, adaptation and co-option that, while taking on board changing realities, still excludes a swathe of less powerful nations that constitute the majority of the UN members [8] [27] [28].

Adjustments made thus far to the workings of the existing international governance system are limited in scope and fragmented and piecemeal in nature. They have also been essentially reactive, rather than proactive. Unsurprisingly, the calls for more comprehensive, integrated reform remain as strong. It is to be expected that the weak and the marginalized in any political order would always have a strong interest in a radical reform programme, in the hope that the changes will offer them more say and benefits. By the same token, the strong and the main beneficiaries from an existing political regime would be most reluctant to embrace any change that could remove their privileges, whittle down their influence, and curb their power, even if they make gestures in favour of reform out of enlightened self-interest [8] [26] [29].

Different regions of the world, or at least countries located in different regions of the world, have sketched out their proposals for reform of particularly the UN, the Bretton Woods institutions, and the post-G7 framework. Their reasons, approaches and ambitions differ, which is why the formal work of reform promises to be a complicated process, to say the least.

The member states of AU have begun harmonizing their individual negotiation positions on major international issues in order to turn their numbers into real political clout in international negotiations. While the African Group has existed in UN processes since the 1960s, in the last two decades it has gained prominence for pro-active approach in some cases and for advancing nuanced and distinct positions in key international negotiations. The idea of a discernable common African agenda is also gaining currency in all global multilateral forums. The strengthening of continental and regional integration has given further impetus to this notion of concerted diplomacy by Africa [8].

These common interests have been most acutely seen in the common African position on UN reform and climate change. African states approach negotiations through formation of a harmonized position based on agreed principles for negotiations and common sets of demands and the building of alliances to further these. The challenges of a harmonized African position include how to leverage a regional approach in a global system that still sees states as the main actor in negotiations; and how to form a common regional position while still allowing flexibility for bargaining concessions.

The RECs are considered the building blocks of AU yet there is no effective interface between the AU Com- 
mission and the RECs, and the RECs only have an observer status in the AU. There is inadequate institutional mechanism to coordinate this interface especially at the political level because the Committee of African Ministers of Integration remains an ad-hoc body [8].

The AU remains an intergovernmental organization whose decisions are still driven by interests of individual member states. The failure of AU to transform into a supranational organization has undermined the ability of the Africa Group to present a concretized common position. While the intention has been to turn the institution into a supranational body underpinned by shared sovereignty, nation states are reluctant to cede any sovereignty to the organization in order to enable it to independently pursue the common interests of the continent. For this reason, individual state's interests tend to compromise the shared interests that common positions epitomize. This is why member states tend to chose one or more of them to champion or manage its common position instead of mandating the chairpersons of AU and AUC to represent their common interests [8].

The idea of a concerted negotiating position is weakened by lack of a framework for coordinating of external relations by RECs and AU. As a result, both RECs and AU conduct international relations separately and often in competition with each other. There is very little evidence of alignment of RECs' international relations and Africa Common Positions. The draft protocol on relation between the AU and RECs is vague on this matter, only pointing out RECs should ensure that their international engagements are in harmony with harmonized policies and programmes between the two tiers of continental governance [8].

National interests of individual African countries have tended to prevent consensus on compromises to be made. There is intransigence on the part of individual countries, part of which has to do with discomfort of some about the power and influence of a few big countries. The compromise mechanisms tend to over-estimate the ability of the AU central organs to manage continental diplomacy when the power still lies with national capitals. By and large, there is no room for compromise during negotiations because it is often extremely difficult for AU to work out areas of compromise beforehand because that would require difficult internal negotiations [8].

There is need for institutionalization of AU-UN peace and security cooperation since the two organizations are complementary to each others efforts and individually bring comparative advantages based on resources, experience and knowledge of realities on the ground. The 2000 AU Constitutive Act and the 2002 AU Peace and Security Council Protocol provide the legal framework for the AU cooperation with the international community and the UN in particular. Africa has resolved to determine its future destiny and is increasingly placing African problems on the international agenda. In the final instance, the AU-UN cooperation is situated within the framework that suggests unless democratization, institutionalization of good governance and economic stability takes root in the continent, peace will remain illusive and peace efforts a self-perpetuating industry [28].

African leaders will need to develop as united an approach as possible, working on three levels; international, regional and national.

On the wider international agenda of the UN, the Bretton Woods institutions, the EU, the G8, the US and other bilateral parties, the adoption of an integrated approach to African problems, including political, developmental and economic dimensions must become a first priority. African leaders will need to promote this actively, international attention for Africa is still too often only the result of determined action by groups and individuals outside Africa.

Africa's own agenda should be as sharply focused as possible and to this end the African Union, regional organizations including SADC, ECOWAS and IGAD, EAC and individual countries, notably those with sufficient capacity, such as South Africa, Nigeria and Egypt, should consider action in the most adversely affected areas of the continent as a first priority. While Africa is increasingly capable of preventing, managing and resolving conflicts, additional resources and enhanced political commitment are urgently required.

Across the continent, five themes are emerging as increasingly central: increased peace, security and stability through conflict prevention, management and resolution; good governance and good policy; investing in people, by improving health and education and combating HIV/AIDS; pro-poor growth through support for the private sector in Africa; and sustainable development, focusing on the management of natural resources, environment and water.

The governance reform process underway in the IMF will (slightly) redistribute voting power between developed and developing nations. The lack of adequate representation of Africa has been specifically acknowledged by building protection for African votes into the framework for reform, and by designing other mechanisms for African states to have power (an extra representative on the Board and more frequent meetings with management). Governance reform at the World Bank usually mimics that of the IMF. As has been pointed out in previous ODI 
publications, the proposed reforms therefore will do little to raise Africa's total voting power, and therefore voice at either institution. African countries should work to ensure that, like the European Union, the African Union becomes a member of the WTO.

Capacity is also a critical issue for the role of regional organizations. For the AU, its ability to contribute to or lead mediation efforts in conflict resolution would be significantly enhanced with greater institutional capacity and expertise [30]. As Tom Tieku argued, the advent of the AU saw regional leadership of negotiations in Burundi improves markedly on the protracted process led by the OAU. Nevertheless the complexities and nuances of such negotiations demand skilled mediators able to draw on substantial expert and institutional back up if the failures of that process are to be overcome [30]. John Kabia also highlighted limited funding provided by member states, the level of corruption and the weak economic conditions as factors which undermine the efficacy of regional organizations like ECOWAS [31]. Even in Africa's most developed state, South Africa, concerns arise about its ability to draw on enough expertise to effectively manage and lead the climate change negotiations as chair and host of the Durban 2011 round [32].

Africa needs to fund its own training of technical capacity, which is happening through AERC, MEFMI, and some other regional and sub-regional organizations. It needs to campaign on voting issues in a more united way, for example agreeing on a rotating seat in the Security Council rather than continuing to fight over which one or two countries should have a seat. Larger African countries could give smaller low income countries more say. Analyze donor policies for themselves and hold them mutual accountable on all the above issues.

The inability of African countries to forge a much more coherent identity and consistently maintain a united stance on a wide range of issues means that African countries are at a disadvantage when it comes to promoting the continent's interests.

\section{Conclusions}

My discussion has shown that for a region or continent to have an impact globally, it needs to process the following: firstly, a critical mass of numbers; secondly, acting as a cohesive regional or continental grouping; thirdly, possessing economic and military muscle; fourthly, the ability to have a common identity that can be used to shape common interests at the global level.

The discussion has shown that although Africa has a critical mass of numbers it lacks both cohesiveness as well as economic and military muscle to shape the global agenda. Africa has also been vulnerable to divide and rule from both Western and Eastern powers as well as rising powers alongside global multinationals. The end result is that by entering bilateral agreements she loses her bargaining power from a continental or regional perspective.

Arising from the foregoing, to give Africa relevance in the global scene, it should focus on a twin approach premised on a reformed international system and integrated approach in shaping the agenda in the international system.

\section{References}

[1] Olukoshi, A. (2016) International Governance Reform in the Africa-European Union Partnership. EU-Africa Political Dialogue on Global Issues of Common Concern. http://europafrica.files.wordpress.com/2009/07/beyond-development-aid.pdf

[2] Swagerty, R.S. (2012) Power, Interests, and Representation in Global Governance. Presentation at the 2012 Annual Meeting of the Midwest Political Science Association, Chicago, 12-15 April 2012, 12-15.

[3] Akokpari, J.K. (2001) Post-Cold War International Relations and Foreign Policies in Africa: New Issues and New Challenges. African Journal of International Affairs, 4, 34-55.

[4] Lehmann, V. (2008) The Relationship between Africa and the UN: From Disenchantment to a More Effective Cooperation. FES Conference Report, Tarrytown, New York.

[5] Murithi, T. (2006) Towards a Symbiotic Partnership: The UN Peacebuilding Commission and the Evolving AU/ NEPAD Post-Conflict Reconstruction Framework. In: Adebajo, A. and Scalon, H., Eds., A Dialogue of the Deaf: Essays on Africa and the United Nations, Jacana Media, Sunnyside, 20-32.

[6] Elkind, J.B. (1988) The Duty to Appear before the International Court of Justice. International and Comparative Law Quarterly, 37, 674-681. http://dx.doi.org/10.1093/iclqaj/37.3.674

[7] Posner, E.A. and Miguel, F. (2004) Is the International Court of Justice Politically Biased? Working Paper from International Law Workshop UC Berkeley. 
[8] Zondi, S. (2011) Africa in International Negotiations: A Critique of African Common Positions. CHATHAM House Seminars.

[9] Hoste, J.C. (2011) Where Was United Africa in the Climate Change Negotiations? Africa Policy Brief, Egmont Institute, Belgium. Africa in International Negotiations, Chatham House, London, 3 February 2011.

[10] Economic Commission for Africa, ECA (1989) African Alternative Framework to Structural Adjustment Programs for SocioEconomic Recovery and Transformation (AAF-SAP). ECA, Addis Ababa.

[11] Andemichael, B. (1994) OAU-UN Relationship in a Changing World. In: El-Ayouty, Ed., The Organization of African Unity after Thirty Years, Prager. London.

[12] Andrews, K.N. and Holt, V.K. (2007) United Nations-African Union Coordination on Peace and Security in Africa. Future of Peace Operations Program. The Henry L. Stimson Centre, New York.

[13] Limpach, S. and Michaelowa, K. (2010) The Impact of World Bank and IMF Programs on Democratization in Developing Countries. University of Zurich, Center for Comparative and International Studies (CIS).

[14] Barro, R.J. and Lee, J. (2003) IMF Programs: Who Is Chosen and What Are the Effects? Departmental Working Papers 2003-09, Australian National University, Economics RSPAS, 1-54.

[15] Barro, R.J. and Lee, J. (2005) IMF Programs: Who Is Chosen and What Are the Effects? Journal of Monetary Economics, 52, 1245-1269. http://dx.doi.org/10.1016/j.jmoneco.2005.04.003

[16] Nelson, S. and Wallace, G. (2005) Conditional Credibility: Explaining the Impact of the IMF on Democratization. The Annual Meeting of the American Political Science Association, Washington DC, 1-5 September 2005, 1-5.

[17] Abouharb, M.R. and Cingranelli, D. (2007) Human Rights and Structural Adjustment: The Impact of the IMF and World Bank. Cambridge University Press, Cambridge.

[18] Dürr, J., Katharina, M. and Vollenweider, J. (2008) Poverty Reduction Strategies, Democratization and the Role of the World Bank. Center for Comparative and International Studies, CIS Working Paper 39, 1-34.

[19] Eberlei, W. (2001) Institutionalized Participation in Processes beyond the PRSP. Deutsche Gesell-schaft für Technische Zusammenarbeit (GTZ), Berlin.

[20] Molenaers, N. and Robrecht, R. (2003) The World Bank, Participation and PRSP: The Bolivian Case Revisited. European Journal of Development Research, 15, 133-161. http://dx.doi.org/10.1080/09578810312331287515

[21] Independent Evaluation Office-IMF (2004) Report on the Evaluation of Poverty Reduction Strategy Papers (PRSPs) and the Poverty Reduction and Growth Facility (PRGF). Independent Evaluation Office, IMF, Washington DC.

[22] World Bank \& IMF (2005) 2005 Review of the PRS Approach: Balancing Accountabilities and Scaling up Results. World Bank and IMF, Washington DC.

[23] Driscoll, R. and Alison, E. (2005) Second-Generation Poverty Reduction Strategies: New Opportunities and Emerging Issues. Development Policy Review, 23, 5-25. http://dx.doi.org/10.1111/j.1467-7679.2005.00274.x

[24] Booth, D. (2003) Introduction and Overview. Development Policy Review, 21, 131-159.

[25] World Bank (2003) Toward Country-Led Development. A Multi-Partner Evaluation of the Comprehensive Development Framework. The World Bank, Washington DC.

[26] Aning, K. (2007) Africa: Confronting Complex Threats. IPA Coping and Crisis, Working Paper Series.

[27] Alemazung, J.A. (2010) Post-Colonial Colonialism: An Analysis of International Factors and Actors Marring African Socio-Economic and Political Development. The Journal of Pan African Studies, 3, 16-25.

[28] Francis, D. (2006) Uniting Africa: Building Regional Peace and Security Systems. Ashgate Publishing Limited, Hampshire.

[29] Neething, T. (2009) Whither Peacekeeping in Africa: Revisiting the Evolving Role of United Nations. African Security Review, 18, 1-20. http://dx.doi.org/10.1080/10246029.2009.9627511

[30] Tieku, T.K. (2011) Lessons Learned from Conflict Management: The Case of Burundi. Paper Presented to the Seminar, African Agency in International Politics: Peace, Conflict and Intervention, 7 April 2011.

[31] Kabia, J. (2011) Regional Approaches to Peacebuilding: The ECOWAS Peace and Security Architecture. Paper presented at the BISA-Africa and International Studies ESRC Seminar Series: African Agency in International Politics African Agency in Peace, Conflict and Intervention, University of Birmingham, 7 April 2011.

[32] Chevallier, R. (2011) Towards the Climate Change Summit in Durban: The Role of the South African Government as an Agent of Change in Africa. Paper Presented to the Seminar, African Agency: Transnational Security Challenges: Migration Health and Climate Change, University of Kent, 16 June 2011. 